\title{
Community-Based and Integrated Solid Waste Management: Experiences from Metro Manila's Tondo District
}

\section{Zortea M1*, Bonis MD², Pupa F³ ${ }^{3}$ Ripaldi G4 and Cucculelli F5}

${ }^{1}$ Department of Civil, Environmental and Mechanical Engineering, University of Trento, Italy

${ }^{2}$ Faculty of Forli, University Alma Mater Studiorum, Italy

${ }^{3}$ Department Economics, University of Rome Tor Vergata, Italy

${ }^{4}$ Department of Sustainable Science and Technologies, Polytechnic University of Catalunya, Spain

${ }^{5}$ School of Political Sciences, University Alma Mater Studiorum, Italy

*Corresponding author: Massimo Zortea, Department of Civil, Environmental and Mechanical Engineering, UNESCO Chair in Engineering for Human and Sustainable Development, University of Trento, Via Mesiano nr. 77, Trento, Italy, Tel: +39.347.1416464; Email: massimo.zortea@unitn.it

\section{Abstract}

An improper solid waste management system creates serious negative impacts both on the environment and on human health. This article analyses as case study the urban main reality of Philippines, Metro Manila, focusing specifically on Tondo District. According to the National Solid Waste Management Commission (NSWMC), in 2016, 40,000 tons of waste was produced daily in Philippines, of which 12,000 remained uncollected, and the country is considered the largest contributor of plastic in the ocean. The World Bank estimated that the production of waste would increase by $165 \%$, doubling in 2025. These data show how the problem of solid waste management and collection in Philippines, especially in urban areas, requires immediate attention and solutions. In addition, in most cases, the waste management (WM) system organized by the Baranguays - the smallest administrative divisions in the country - is inadequate, and integrated by unofficial and in large part not legalized systems, which separate and sell waste to companies who recycle or reuse it. The research conducted in field analyses the waste chain in the Philippines, explaining how a more efficient Urban Solid Waste Management could produce a positive impact on people and on the environment. In Tondo District the presence of unofficial actors, such as cooperatives, under certain conditions could be a valuable supply chain that would reduce the amount of waste in streets and landfills, integrating the work of the most vulnerable groups, such as women and scavengers. The research main finding is that it would be necessary not only to implement LGUs (local government units, including provinces, independent cities, municipalities and Barangays) policies on solid waste management (SWM) but also to adopt a community-based approach in the official waste chain. 
Keywords: Sustainable Development; Urban Solid Waste (USW); Integrated Solid Waste Management; Communitybased Approach; Waste Chain

\section{Introduction}

The Philippines are facing an unprecedented economic growth, rapid population arising, urbanization, and an improvement in the living standards. Despite these progresses, solid waste management remains a critical problem, especially in urban areas such as Metro Manila, mainly because to improper waste disposal, inefficient waste collection and lack of disposal facilities [1].

According to the NSWMC, in 2016, the country generated 40,087.45 tons of waste, and these data are estimated to grow up as a consequence of the changes in the economy and the population's growth [1]. In the same year, Metropolitan Manila, with an estimated population of 12 million people, produced 9,212.92 tons per day of wastes. In addition, the country is responsible for the production of estimated 2.7 million metric tons of plastic waste annually and is the largest contributor of plastic in the ocean, amounting to 0.5 million metric tons per year [2].

In the country, the local government units (LGUs) are responsible of the collection, transport and disposal of solid waste, as stated in the National Solid Waste Management Act of 2000. When LGUs do not administer their own collection system, they contract this service to external companies. However, some areas, such as poor district and regions inside the municipalities and the cities, and rural Barangays, remain unserved or underserved [1].

Many local government units are encountering several difficulties in organizing garbage segregation and corresponding handling of segregated wastes, promoting recycling and institutionalize waste minimization policies. According to the Senate Economic Planning Office in 2016, there were 403 opened dumpsites and 108 controlled dumpsites in operation, even if open dumping are declared illegal under RA 9003, which required to close them by 2006 and established closed dumpsites and sanitary landfills (SLFs). In addition to all these issues, in the country there is also scarcity of new landfill sites for the growing number of garbage generated by the Filipinos. In fact, the number of SLFs remain largely insufficient to service the LGUs [1].
This situation poses under a huge pressure the environment and creates high risks for public health. These polluting disposal facilities are major sources of greenhouse gas emissions to the atmosphere, which adds to global warming. Landfills and open dumps, according to studies, account for 34 percent of human-related methane emissions in the atmosphere, and methane is a global warming gas that has 23 times more heat-trapping power than carbon dioxide [3].

Inadequately managed waste contributes to the contamination of water and soil and leads to air pollution, which creates cancer illnesses, vector-borne diseases, birth defects, immune system problems and childhood developmental issues [2]. In the dump sides but also in the centre of Metro Manila the uncollected waste causes floods and pollutes the major water resources by the production of leachate, or "garbage juice".

This article outlines the main challenges that the country and Metro Manila in particular are facing in terms of solid waste management, and also highlights some best practices and virtuous projects implemented in the area that could contribute to mitigate the problem. Eventually, a community-based approach and an integrated Solid Waste Management becomes to be experimented in the Metro Manila context and can be expanded to many other realities in a not far future.

\section{Legislative Context}

The legislative framework in waste management, which all the municipal authorities are aligned to, is contained in the Republic Act (RA) No. 9003. Another significant reference is the Ecological Solid Waste Management Act (2000). The Philippines Republic decided to undertake a concrete action at the beginning of 2000 , because the country was starting to face serious problems related to garbage management, dated back at the beginning of the 70ies [4].

The Republic Act RA 9003 deals mostly with public health, environment and, clearly, all the societal issues that come from a bad management of solid waste. The RA aims, in fact, at a "proper segregation, collection and transport" of the garbage through the adoption of concrete environmental practices [4]. The Philippine Congress adopted the RA 9003 on December 20th of 2000 
and it came into force during January 2001. It is a wide document, comprehensive of various annexes that explain the different practices and policies to be used for a proper management and segregation of every type of waste, referring especially to solid waste [4].

Two main bodies were established in charge of solid waste segregation: the National Solid Waste Management Commission (NSWMC) and the Solid Waste Management Board (SWMB). The two entities had to be established by all the Local Governments and had the supervision of the private and public sectors, in terms of waste policies. The function of the Commission is coordinating all the activities regarding the development and implementation of NSWM- National Solid Waste Management [5]. The Board has a 10 years mandate, to be implemented on a 10 years plan about Ecological Solid Waste Management that, in the first period (since its institutionalization), was mainly based on recycling and composting. Both the bodies- NSWMC and SWMB-along the years haven't demonstrated much effectiveness and, most of the times, the Local Governments tend to use their own regulations on waste management [5]. Although the Commission of National Solid Waste Management encourages the adoption of local development plans, in relation to the social and economic development of each province, it's difficult to have a uniform prospect of the entire country situation in terms of waste management policies and actions, also because the disposal facilities are not coordinated under a unique governmental bodies but under local Barangays.

\section{The Tondo District}

The geographic area of Tondo District is the home for one of the biggest urban poor communities. Included in that area, the Smokey Mountain in Balut Island was once known as the largest landfill, where thousands of impoverished people live in slums. After the closure of the landfill in 1995, mid-rise housing buildings were built in place. This district also contains the Manila North Harbour Centre, the Manila North Harbor, and the Manila International Container Terminal of the Port of Manila. In Tondo District a significant actor for people human development is the Don Bosco TVET and Youth Center. Direct beneficiaries of the Centre are 709 students and 491 staff members; indirect are their families and the local community. The Centre has studied and actually is beginning a sustainable Waste Management project based on the role of local communities. The global range of householders potentially involved by the project will be some 9000 people and some 2000 households. The initiative will rely on support and collaboration from the local government: the Don Bosco TVET and Youth Centre will work closely with the local Barangay and will involve the local authorities, both at Barangay and municipal level, through a series of mutually agreed activity.

The waste produced by the Centre are: plastic (water plastic bottles and other types of plastic), organic (mainly food leftover), paper, non-recyclable materials, and other type of waste (mainly metal, scraps and fabric produced by the technical and training centres).

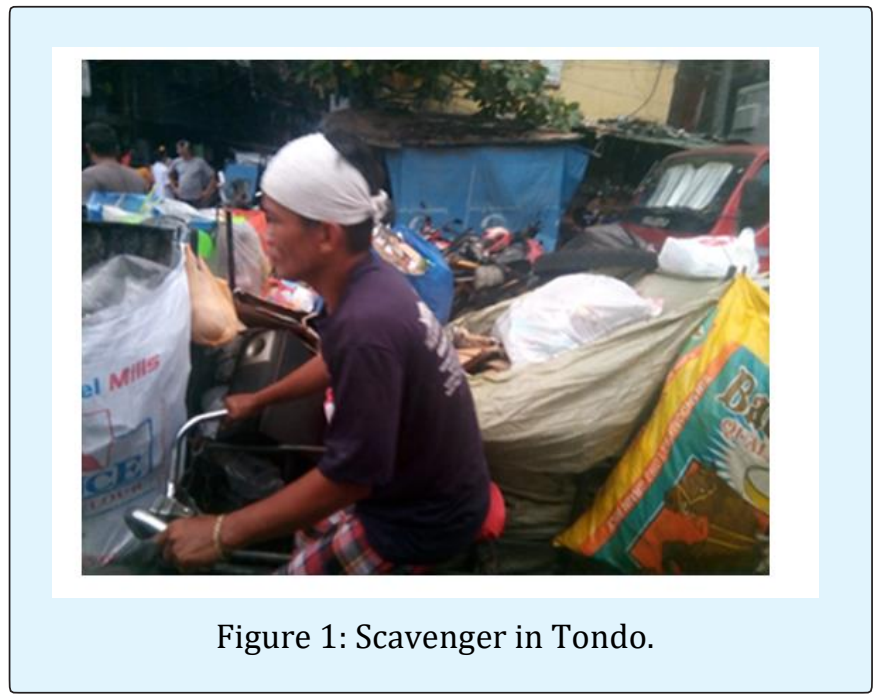

Through the information collected on the spot, we calculated the measure of each type of waste produced in a week in $\mathrm{kg}$, by the number of dump distribute in the Centre. The data are synthesized in the below table:

\begin{tabular}{|c|c|}
\hline Type of Waste & Average Quantity (Kg) \\
\hline plastic & 32.5 \\
\hline paper & 86.512 \\
\hline organic & 289.8 \\
\hline residuals & 85.4 \\
\hline other (metals or fabric) & 31 \\
\hline
\end{tabular}

Table 1: Determination of Average Quantity of Waste.

The experiences and practices of household waste management by people in Tondo District have been documented during our field mission in 2018, thanks to data gathered through interviews with household members using open-ended questions. Interviews were also conducted with garbage collectors as well as scavengers. The official waste management process is organized at the local level by every single Baranguay. The collection is done by trucks. Citizens have not any ordinances about how they should prepare waste for 
collection and generally have not any idea on how the city disposes of its waste. They use plastic bags to collect waste and they separate the kitchen leftovers that are generally used to feed animals and bottles are separated to be sold to junk shops at 1 pesos per kilos. In some areas, there is not any collection point: waste is taken by someone in the house to the waste collection truck, whose passage is scheduled twice a week. In some other areas, collection points are planned. However, the collection system is not efficient and generally waste is not picked up: it remains in the street. Waste that is collected by truck in Tondo, is disposed on a barge in Port Harbour. It is supposed that some waste from this barge is discharged on the sea. Before waste was brought on the so-called Smokey Mountain, that is now closed, reclaimed and edified.

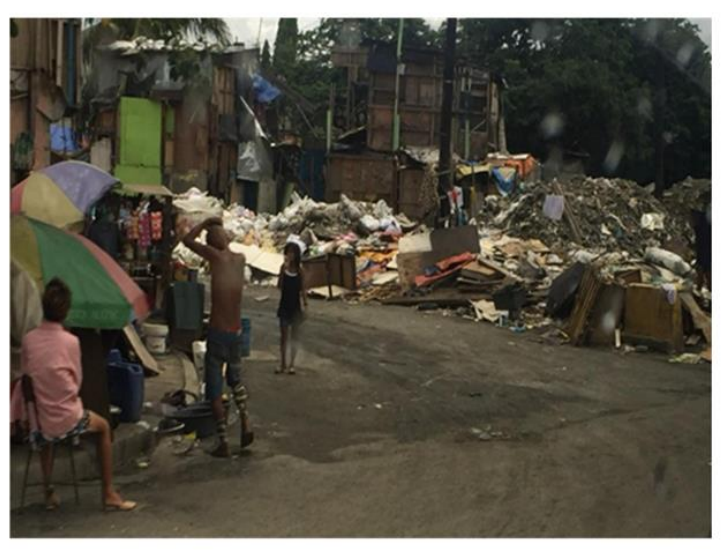

Figure 1: Tondo District, trash in the Street.

On the other side, there is also an unofficial waste supply chain, that existed thanks to in large part not legalized actors. Waste that is not collected by trucks and lied on the street is separated by scavengers or is simply picked up. Then, scavengers take waste to junk shops that buy it. The price per kilo for mixed garbage is 17 pesos, for bottles is 13-14 pesos. A scavenger is able to reach an income of 500 pesos per day. Then, waste is sold by junk shops to recycling factories. The price at which junk shops sold waste is unknown [6].

\section{The Community-Based Approach: Integrated Solid Waste Management}

An interesting initiative studied during our field mission and environmental assessment, in July and August 2018, deserves to be reported, since it can be applied even to Tondo District context: the implementation of a community-based programme aimed at educate community members and develop sustainable initiatives to improve SWM practices, observed by our team in the rural communities of Sant Jose and Calauan (Northern Philippines). Interviews and questionnaires has been carried out by targeting the local communities, students and teachers of the Don Bosco Centre in Tondo District, Junki shop and some cooperatives.

Don Bosco Youth Centre in Tondo has been founded almost 50 years ago. Its technical education has proven its efficiency and effectiveness in serving out-of-school youth. This is evident due to the increasing number of students every year and due to the average placement rate (roughly $85 \%$ to $90 \%$ ) after their training. Don Bosco Youth Centre envisions to do its best in the prevention or mitigation of the waste problem, in order to intensify cleanliness in the environment and to take measures to properly manage plastic materials that play a major role in guaranteeing health benefits starting from humans to aquatic species.

According to our environmental assessment, as above, the recent methods and techniques to transform waste into practical and usable materials beneficial to the people are applicable to the municipal context of Metro Manila, mainly in Tondo suburbs, with special focus on the collection, separation and recycling activities. So that, two important actions are planned to be adopted, one at Barangay level and the other at Don Bosco Centre level.

On one hand, Don Bosco TVET Center in Calauan has a Material Recovery Facility technology that produces bricks from chopped plastic and plastic residuals. Don Bosco Youth Centre in Tondo will partner with Don Bosco TVET Centre in Calauan in order to convert the waste into bricks that can be sold to the localities in a reasonable price. Don Bosco Youth Centre in Tondo will have the role of collector, while Don Bosco TVET Center in Calauan will be the processor center.

On the other hand, seminars and workshops for all stakeholders of the Don Bosco Youth Center in Tondo, together with the Barangay local officials and local community, about the importance of a good and clean environment will be scheduled. Also environmental seminars and trainings during the school activities or community based activities will be arranged. The local Parish, capable to reach many people, will be involved in communicating the seminars and training activities.

The Barangay should act to allow the local community to implement waste segregation in their respective 
household as a contributor in proper waste management. To formalize the work of scavengers as crucial actors for waste management, to organize, form and provide them with appropriate equipment and health safer behaviour. Wide invitation to stakeholders to attend a seminar on the relevance of environmental protection will be promoted. Speakers who are experts in the field from the Department of Environment and Natural Resources (DENR) will be invited.

All the project will adopt a gender approach, equipping the local community's women with practical skills in order to transform the recyclable materials into handicraft products. The final goal is to empower women to learn techniques on how they can utilize recyclable materials as raw materials in the production of goods such as handicrafts, that will generate financial support for their families. In this effort, it will be decisive the partnership with some local cooperatives, such as Sambayanan Multi-purpose cooperative and Papel Women Weavers, a cooperative that we had the opportunity to interview, engaged to produce bags, jewels and domestic stuff from garbage as plastic wrappers, bottles and old magazines (more information can be found at this link: http://povertyenvironment.net/ $\mathrm{adb} /$ projects/photos-smokey-mountain, Turning trash into treasure in Manila's Smokey mountain).

In the frame of all project implementation, the Barangay could involve the youth council or Sangguniang Kabataan in Tondo District as ambassadors of environmental protection. It can contribute to prepare education programmes for young people, helping them understand their role in the protection of the environment, and invite speakers from environmental groups to conduct seminars or training workshops in a regular basis to as many youth as possible [6].

\section{Conclusion}

The attention of the national and local governments on solid waste management's policies and projects is increasing, as reflected by the various initiatives that have been implemented at local and national level. However improper solid waste management is still a major challenge of the country and without a correct waste management policy, Philippines might not be able to manage the worst indirect effects of economic growth.

The proposed evidences outline the importance of promoting a community-based solid waste management and testify that there are several solutions that could be implemented on a local and national scale to mitigate the problems, at least. These initiatives could produce positive effects on the environment, reduce the risks for the human health and encourage the inclusion of the most vulnerable and poor groups, promoting their economic independence.

On a long-term perspective, it is crucial that all the actors involved (LGUs, municipalities, cities, Barangays, households and commercial generators) work together to implement initiatives aimed to avoid or reduce at the origin the production of solid waste, especially that coming from the use of plastic and single-use plastic, also encouraging reuse and recycling initiatives in a circular economy perspective. In this direction, education of young generations is crucial [6].

\section{Acknowledgements}

This paper is based on a research \& action project conducted by Prof. Massimo Zortea (University of Trento, Italy) and his team, in collaboration with VIS onlineCenter for Human Development by VIS NGO (Rome) and the Salesian Province of North Philippines in Summer 2018.

\section{References}

1. Castillo AL, Otoma S (2013) Status of Solid Waste Management in the Philippines, University of Kitakyushu, Japan, pp: 1-8.

2. Senate Economic Planning Office-SEPO Philippine Solid Wastes at a glance, pp: 1-7.

3. UNICEF (2017) Climate landscape analysis for children in the Philippines, UNICEF Philippines, pp: 154 .

4. (2001) Official Gazette-Republic of Philippines, Republican Act No. 9003.

5. Aquino AP, Deriquito JAP, Festejo MA (2013) Ecological Solid Waste Management Act: Environmental Protection Through Proper Solid Waste Practice, FTTC Agricultural Policy Platform.

6. De Bonis M, Cucculelli F, Pupa F, Ripaldi G (2018) Environmental Assessment of Solid Waste Management in Metro Manila and Northern Philippines - Final Report, VIS online Internship Programme, 2018 (Edn.), VIS NGO, Rome. 